\title{
THE DETERMINISTIC CHAOS OSCILLATOR BASED ON A FIELD-EFFECT TRANSISTOR STRUCTURE WITH NEGATIVE RESISTANCE FOR TELECOMMUNICATIONS SYSTEMS
}

\author{
Andriy O. Semenov \\ Vinnytsia National Technical University, Vinnytsia, Ukraine
}

Background. Application of deterministic chaos oscillators in telecommunication systems requires knowledge about their dynamical properties. Mathematical models and phase portraits of such generators are well known. However, common theory of the deterministic chaos oscillators was developed without noise. At the same time, these oscillators are applied in telecommunication systems at presence of both external and intrinsic noises. Therefore, researching the noise impact on oscillation dynamics in the deterministic chaos oscillator is an actual applied scientific task.

Objective. Creating the mathematical models of the Kiyashko-Pikovsky-Rabinovich-type deterministic chaos oscillator based on a FET structure with negative resistance at presence and at absence of additive white noise.

Methods. Chaotic oscillation dynamics in the oscillator was examined on a base of the well known mathematical model of Kiyashko-Pikovsky-Rabinovich and the non-linear approximation of the FET structure's static current-voltage characteristic using the hyperbolic tangent function. The results of the deterministic chaos oscillator mathematical simulation at presence of additive white noise were obtained. The additive white noise impact on generated chaotic oscillation's dynamics and parameters was researched.

Results. The phase portraits, time and frequency dependences for the oscillation in the deterministic chaos oscillator based on a FET structure with negative resistance at presence and at absence of additive white noise have been obtained.

Conclusions. The results of chaotic oscillation dynamics numerical simulation at presence of white noise confirm the high noise immunity of the deterministic chaos oscillator based on a FET structure with negative resistance.

Keywords: oscillator; chaos; oscillation; phase portrait; white noise.

\section{Introduction}

Deterministic chaos oscillators are applied in radio engineering and telecommunications in presence of intrinsic or external noise [1]. Therefore, researching the noise impact on physical processes in deterministic chaos oscillators is an actual scientific problem [2]. This problem is quite complicated because such processes cannot be regarded as only random or only deterministic ones. Intrinsic or external noise sources can considerably impact on a non-linear dynamic system $[3,4]$. The most noticeable noise impact is quantity changes of the generated oscillation dynamics. It takes place in points of the self-oscillating system structural instability, especially in bifurcation points.

The aim of the paper is researching the additive white noise impact on chaotic dynamics of the Kiyashko-Pikovsky-Rabinovich (KPR) oscillator based on a field-effect transistor structure with negative resistance. In the paper, much attention is paid for model researching the noise impact on oscillator's phase portraits and on a shape and spectral characteristics of the generated oscillation.

\section{Theory of the KPR oscillator}

The simplified electric circuit of the KPR oscillator based on the field-effect transistor structure with negative resistance is presented on fig. 1 [5-7]. Different schemes of the transistor structure with negative resistance VT1-VT2 and their properties have been examined in [8].

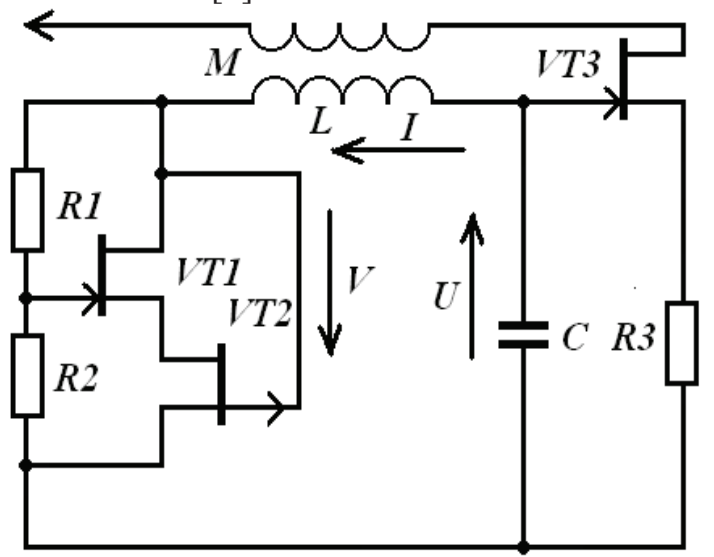

Fig. 1. The simplified electric circuit of the KPR oscillator based on the field-effect transistor structure with negative resistance 
The equivalent circuit of the KPR oscillator based on the field-effect transistor structure with negative resistance is presented on fig. 2.

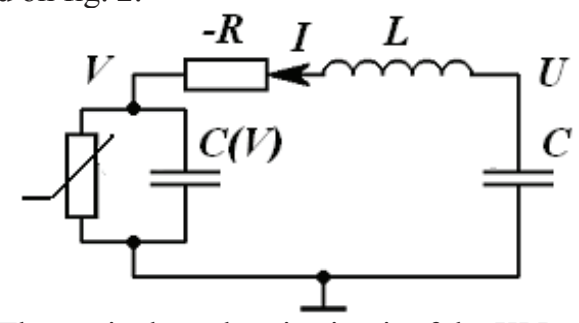

Fig. 2. The equivalent electric circuit of the KPR oscillator based on the field-effect transistor structure with negative resistance

On the equivalent circuit there are marked: $U$ is a voltage on the capacitance C of the generator's oscillatory circuit; I is a current of the inductance coil; $\mathrm{V}$ is a voltage on the transistor structure VT1-VT2, shown as a non-linear resistance in parallel with voltage-controlled capacitance $\mathrm{C}(\mathrm{V})$; $-\mathrm{R}$ is a value of the negative differential resistance brought in by a positive feedback circuit into the generator's oscillatory circuit; L is a value of the equivalent inductance coil (allowing for the mutual inductance $\mathrm{M}$ ); $\mathrm{C}$ is an equivalent conductance of the generator's oscillatory circuit $[6,7]$.

The system of differential equations with normalized variables [6]

$$
x=\frac{I}{I_{m}}, y=U I_{m} \sqrt{\frac{C}{L}}, z=\frac{V}{V_{m}} .
$$

in reference to a normalized time

$$
\tau=\frac{t}{\sqrt{L C}}
$$

looks so $[6,7]$

$$
\left\{\begin{array}{l}
\dot{x}=2 h x+y-g z \\
\dot{y}=-x \\
\varepsilon \dot{z}=x-f(z)
\end{array}\right.
$$

where approximation function of the field-effect transistor structure current-voltage characteristic in normalized variables [7]

$$
f(z)=2.029 \cdot 10^{-3} z+1.217(1-1.042 \cdot z)^{2} \tanh \left(\frac{25 \cdot z}{1-1.042 \cdot z}\right)
$$

The normalized coefficients equation of the system (3) is $[6,7]$

$$
2 h=R \sqrt{\frac{C}{L}}, g=\frac{V_{m}}{I_{m}} \sqrt{\frac{C}{L}}, \varepsilon=\frac{g C(V)}{C} .
$$

The differential equations system (3) and the normalized coefficients equations (1), (2) and (5) are valid if the non-linear capacity $C(V)$ is much less than the capacity $C(C(V) \square C)$ and changes very little in generated oscillation amplitude change range $\left(C(V(t)) \approx C_{0}\right)$. In such a case, a coefficient $\varepsilon$ is regarded as a small parameter $\varepsilon \square 1[7,9]$.

Impact of the field-effect transistor VT3 transfer current-voltage characteristic's non-linearity is considered according to the equation [10]

$$
I_{C T}(U)=I_{0}+S U-\frac{S U^{3}}{3 U_{0}^{2}}
$$

where $U_{0}$ - the cutoff voltage.

With normalized variables considering the impact of the non-linear characteristics of the field-effect transistor VT3 will cause changing the first equation of the system (3) like

$$
\dot{x}=2 h x+y-g z-d x \cdot y^{2}
$$

where

$$
d=\frac{V_{m}}{U_{0}} \sqrt{\omega_{0} \cdot M \cdot S}
$$

In analytical consideration the additive white noise impact is estimated by connecting a noise current source $i_{n}(t)$ in parallel with a non-linear resistance and voltage-controlled capacitance $C(V)$ at the equivalent circuit. In such case the homogeneous system of differential equations (3) transforms in an inhomogeneous one [11]

$$
\left\{\begin{array}{l}
\dot{x}=2 h x+y-g z-d x \cdot y^{2}, \\
\dot{y}=-x, \\
\varepsilon \dot{z}=x-f(z)+\sqrt{2 D} n(t),
\end{array}\right.
$$

where $n(t)$ is a normalized source of Gaussian noise, $\mathrm{D}$ is a noise level. The white Gaussian noise normalized source parameters are $[3,11]$ 


$$
\langle n(t)\rangle=0,\langle n(t) n(t-\tau)\rangle=\delta(\tau)
$$

\section{The Results of Mathematical Simulation the KPR Oscillator without Noise}

The mathematical simulation for the system of differential equations was performed in MathCad 15.0. The differential equations system was solved by using the Runge-Kutta method of the 4-th order with the standard function $\operatorname{rkfixed}()[9,11]$. The phase portraits in dynamic range of the generated oscillations without noise when $\mathrm{g}=0.957$ and $\mathrm{d}=0.2$ are shown on fig. 3 .

The change of the normalized coefficient $h$ impacts on a change of pulse quantity $z$ on the distance between them. This defines quantity and length of the oscillation packets at the oscillator's chaotic mode.
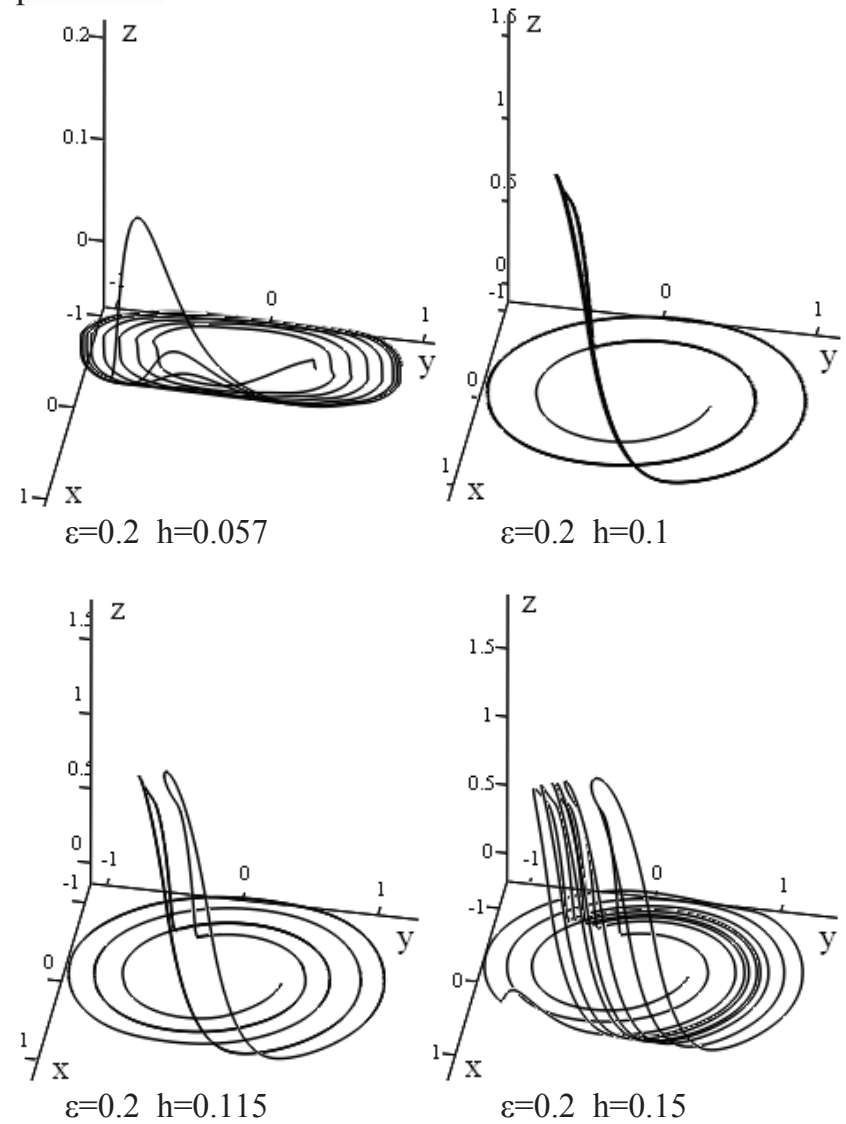

Fig. 3. Phase portraits of the KPR oscillator without noise when $\mathrm{g}=0.957$ and $\mathrm{d}=0.2$

In the paper the KPR oscillator operating mode taking place on conditions when $\mathrm{g}=0.957, \mathrm{~d}=0.2, \varepsilon=0.2$, $\mathrm{h}=0.15$ was examined more particularly. The results of simulation the oscillator operation chaotic mode without noise are presented in fig. $4-$ fig. 5 . The time graphs of normalized variables are shown in fig. 4 . The oscillator phase portrait in a space of $x-y-z$, and its projection in planes of $x-y, x-z$ and $y-z$ are shown on fig. 5.
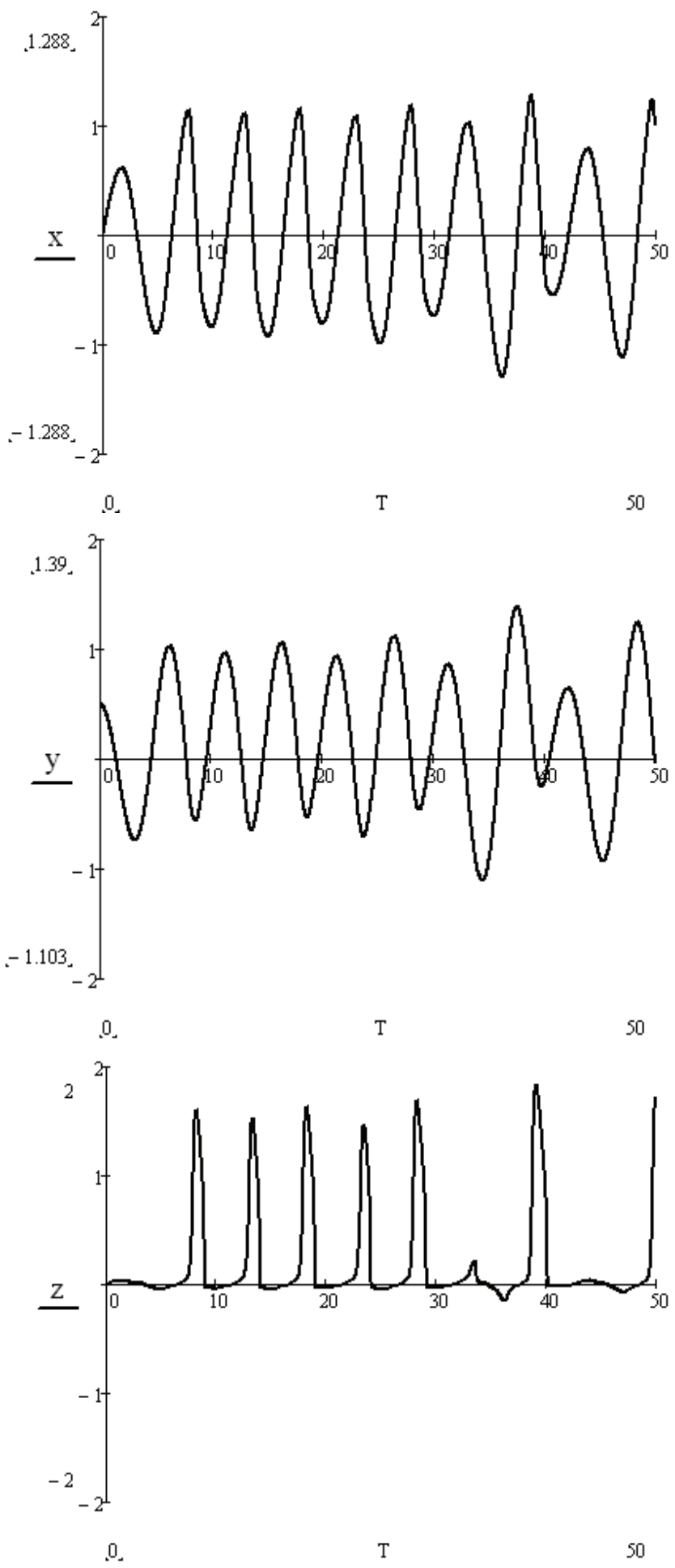

Fig. 4. The graphs of normalized variables $x, y$ and $z$ depending on normalized time $T=\omega_{0} t$, when $\mathrm{g}=0.957$, $\mathrm{d}=0.2, \varepsilon=0.2, \mathrm{~h}=0.15$ 

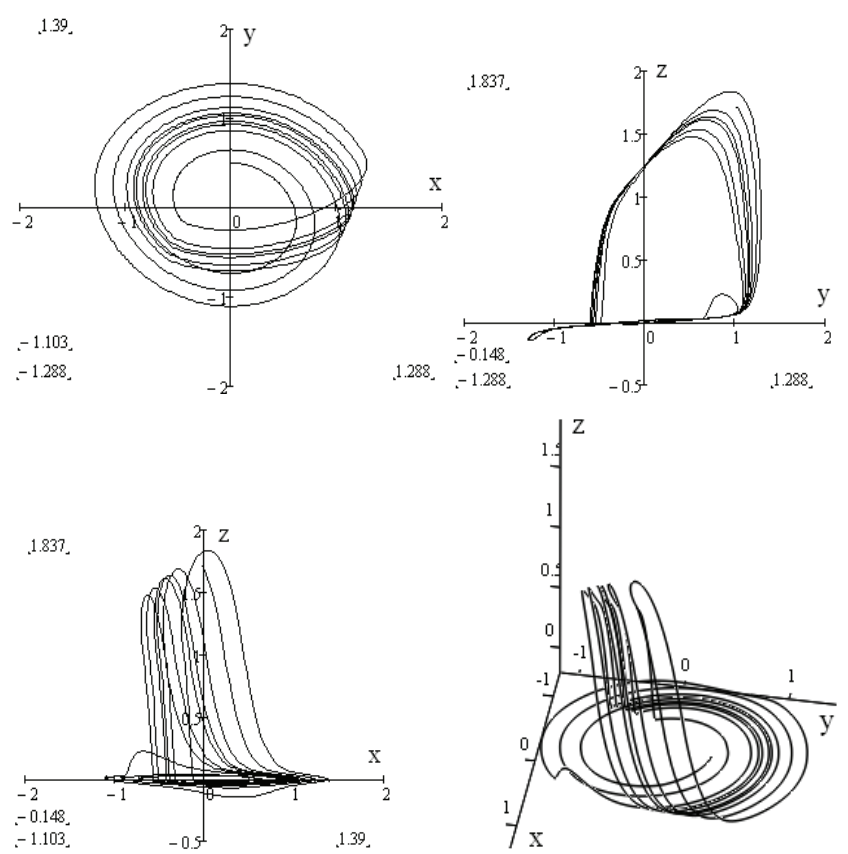

Fig. 5. The KPR oscillator phase portraits when $g=0.957$, $\mathrm{d}=0.2, \varepsilon=0.2, \mathrm{~h}=0.15$ in planes of $\mathrm{x}-\mathrm{y}, \mathrm{x}-\mathrm{z}, \mathrm{y}-\mathrm{z}$ and in a space of $\mathrm{x}-\mathrm{y}-\mathrm{z}$

\section{The Results of Mathematical Simulation the KPR Oscillator in Present of White Gaussian Noise}

In the paper the KPR oscillator operating mode taking place on conditions when $\mathrm{g}=0.957, \mathrm{~d}=0.2, \varepsilon=0.2$, $\mathrm{h}=0.15$ was examined more particularly. The results of researching the dynamic processes in the KPR oscillator in presence of noise when $\mathrm{g}=0.957, \mathrm{~d}=0.2$, $\varepsilon=0.2$ and $\mathrm{h}=0.15$ at different $\mathrm{D}$ levels are shown on fig. 6. The KPR oscillator phase portrait projections in a plane of variables at different additive white Gaussian noise intensity levels D are shown in fig. 7 - fig. 9.
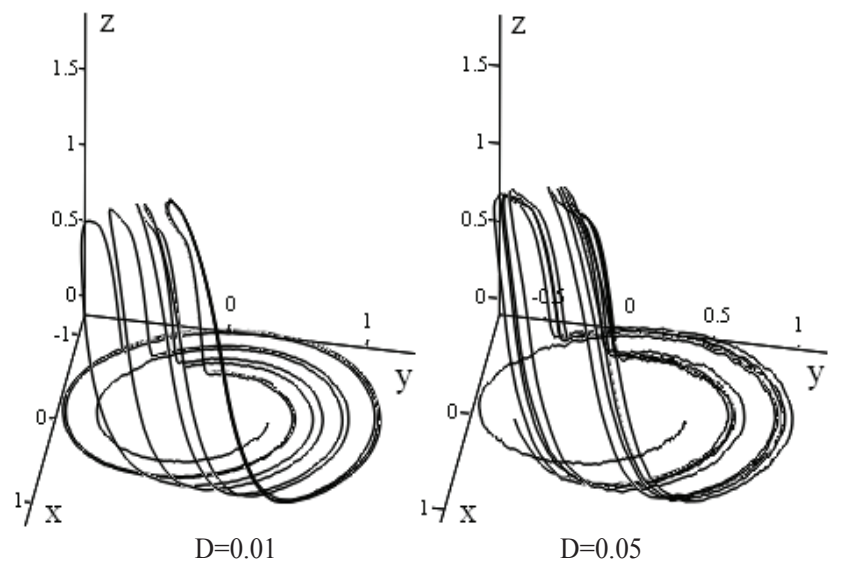

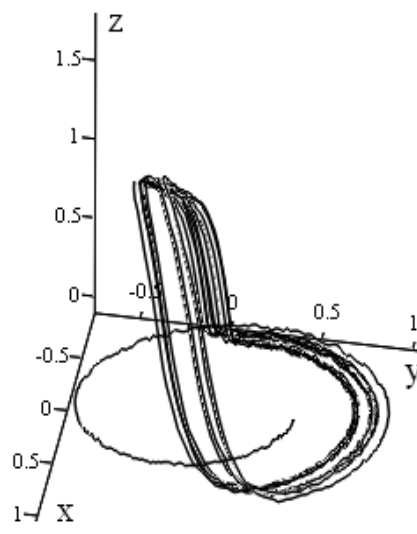

$\mathrm{D}=0.1$

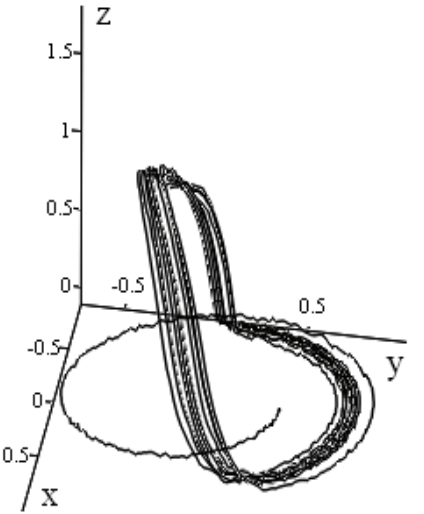

$\mathrm{D}=0.15$
Fig. 6. Phase portraits of the KPR oscillator's in presence of white Gaussian noise when $\mathrm{g}=0.957$ and $\mathrm{d}=0.2$

The results of simulation the oscillator operation chaotic mode with noise are presented on fig. 7 - fig. 12. The amplitude and phase spectrums of the oscillations in presence of white noise at different $\mathrm{D}$ levels are shown on fig. 10 - fig. 11.
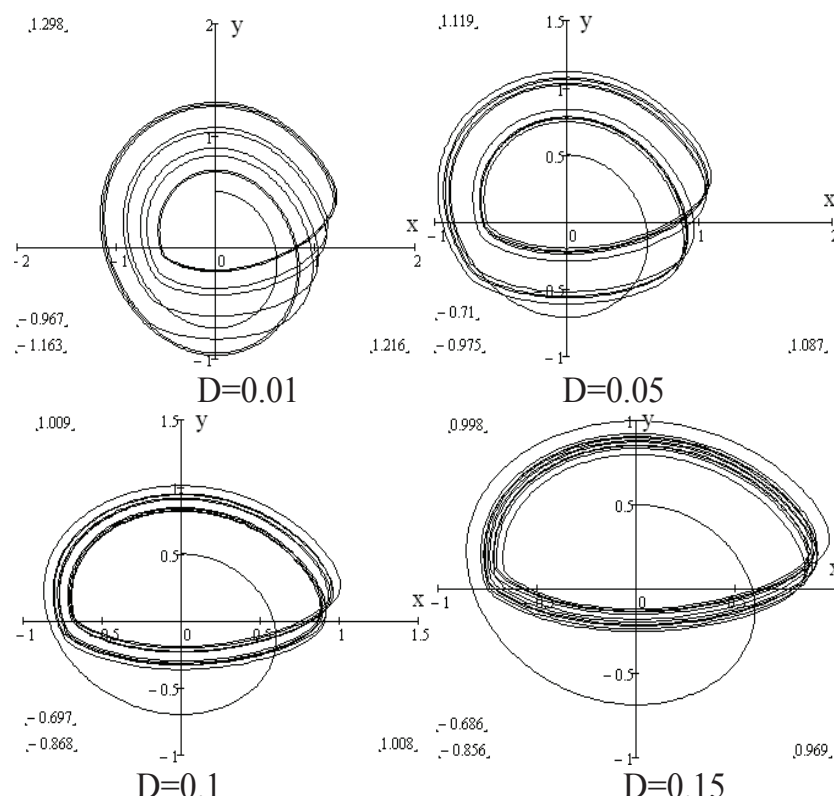

$\mathrm{D}=0.05$

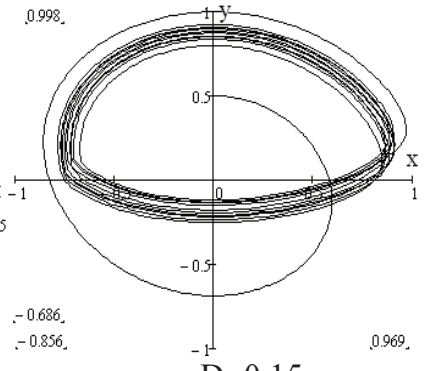

$\mathrm{D}=0.15$

Fig. 7.The phase portraits of the chaos oscillator in planes of $\mathrm{x}-\mathrm{y}$

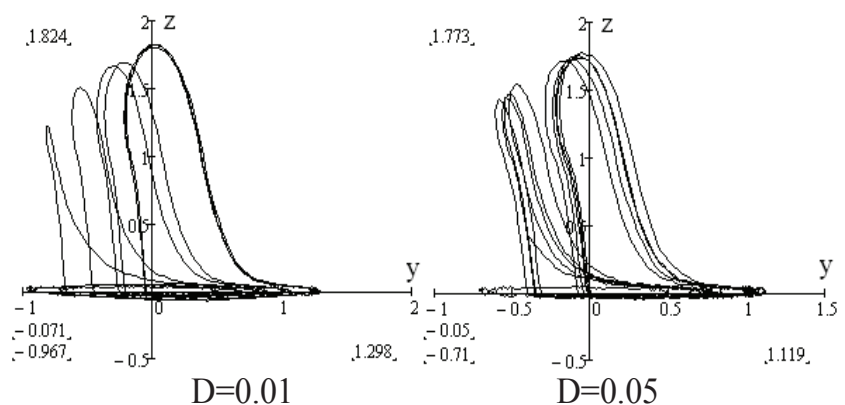




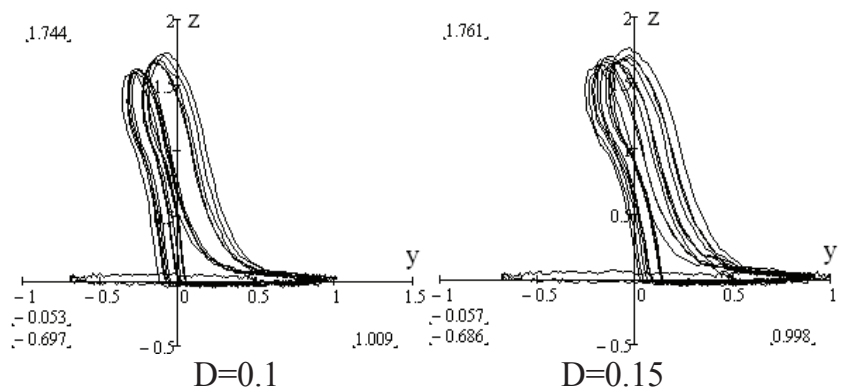

Fig. 8. The phase portraits of the chaos oscillator in planes of $\mathrm{y}-\mathrm{z}$
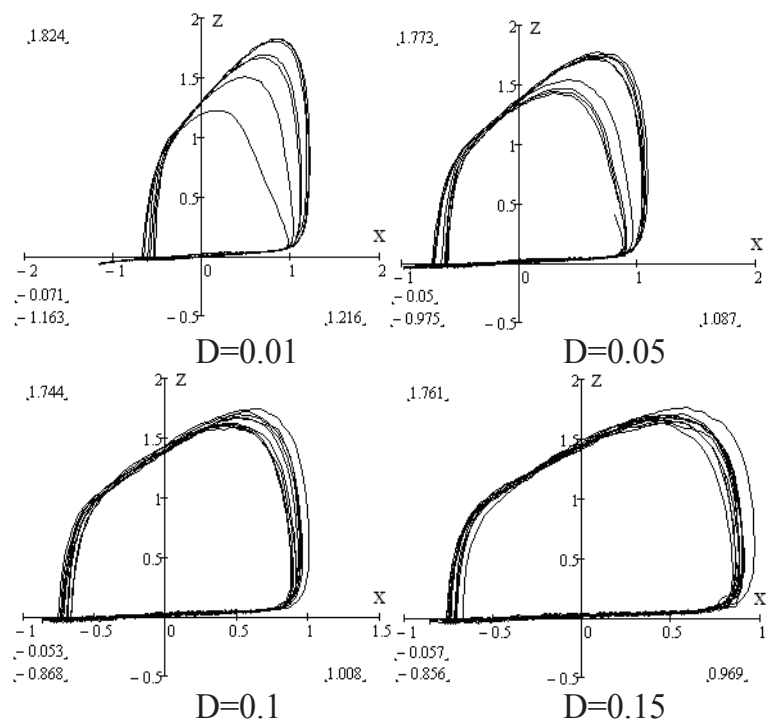

Fig. 9. The phase portraits of the chaos oscillator in planes of $\mathrm{X}-\mathrm{Z}$
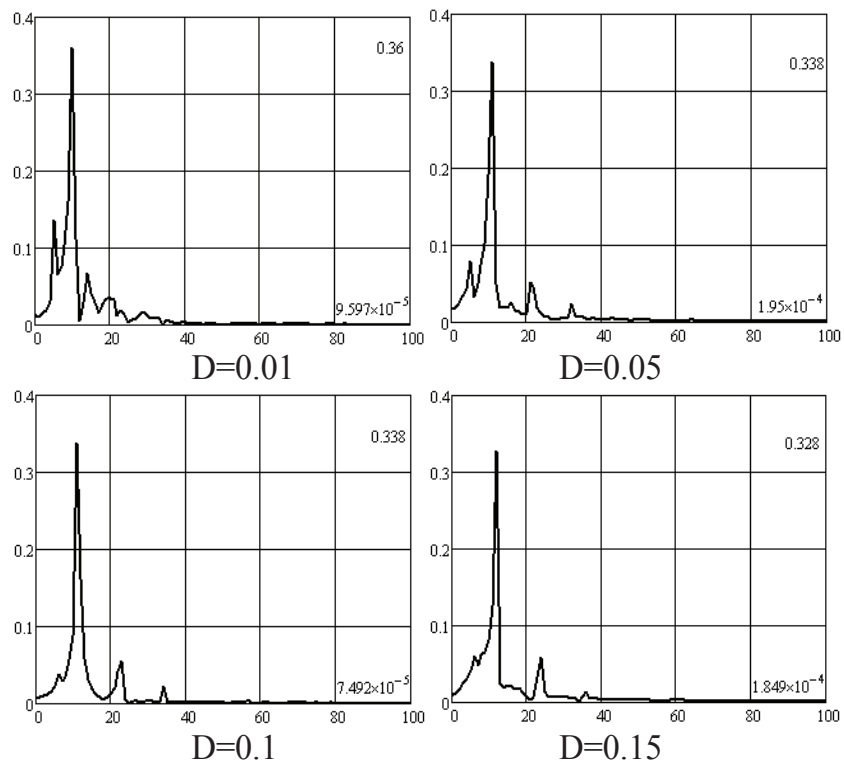

Fig. 10. The amplitude spectrum of the oscillation variable $\mathrm{x}$ in presence of white Gaussian noise when $\mathrm{g}=0.957, \mathrm{~d}=0.2$, $\varepsilon=0.2$ and $\mathrm{h}=0.15$
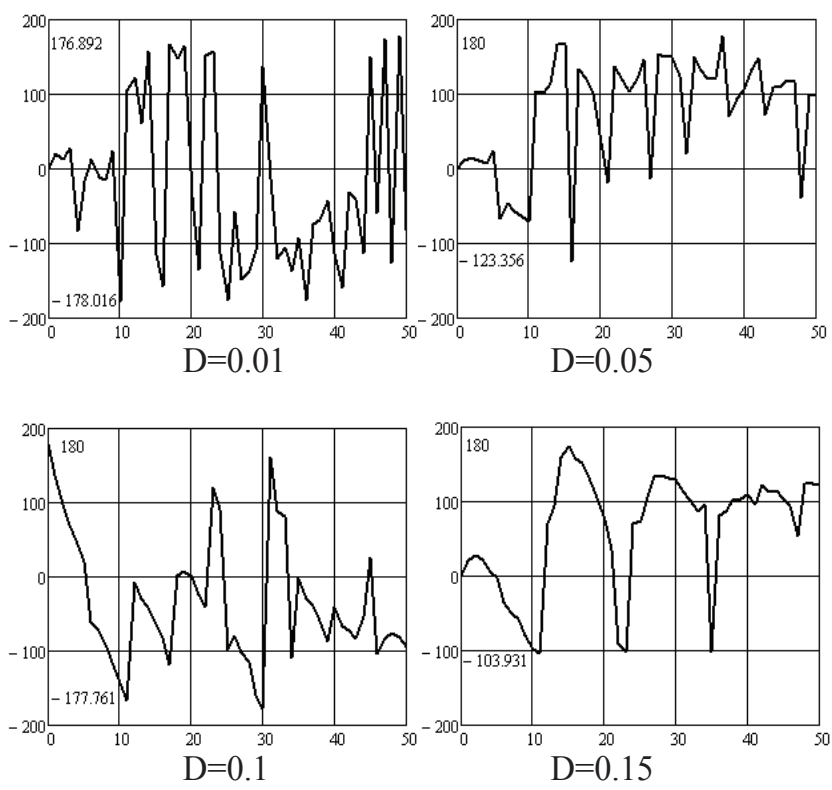

Fig. 11. The phase spectrum of the oscillation variable $\mathrm{x}$ in presence of white Gaussian noise when $\mathrm{g}=0.957, \mathrm{~d}=0.2$, $\varepsilon=0.2$ and $\mathrm{h}=0.15$

Increasing the white noise intensity has a great impact on phase portraits of the KPR oscillator as can be seen from the simulation results (fig. 6 - fig. 9). This causes transition from chaotic oscillations (fig.12, a) to stochastic oscillations (fig. 12,b,c), and then to quasi-harmonic oscillations with spurious amplitude and phase modulations. The appearance of quasiharmonic oscillations is proved by the phase portrait limiting cycle creation in fig. 7 - fig. 9 at $\mathrm{D}=0.1$ and $\mathrm{D}=0.15$.

The white noise impact on chaotic oscillators is known from the chaotic oscillation theory to cause the coherent resonance effect at some bifurcation modes (the Hopf bifurcation, period-doubling bifurcation).

The examination of the amplitude-frequency (fig. 10) and phase-frequency (fig. 11) oscillation spectra shows the coherent resonance effect not to take place at the considered operation mode the KPR oscillator

The qualitative time graphs of the normalized variable $x$ oscillation are shown in fig. 12. As one may see from fig. 12, increasing the white noise intensity causes the qualitative transition from chaotic oscillations packets (fig. 12,a) to complicated stochastic oscillations (fig. 12,e) with random amplitude and phase. 

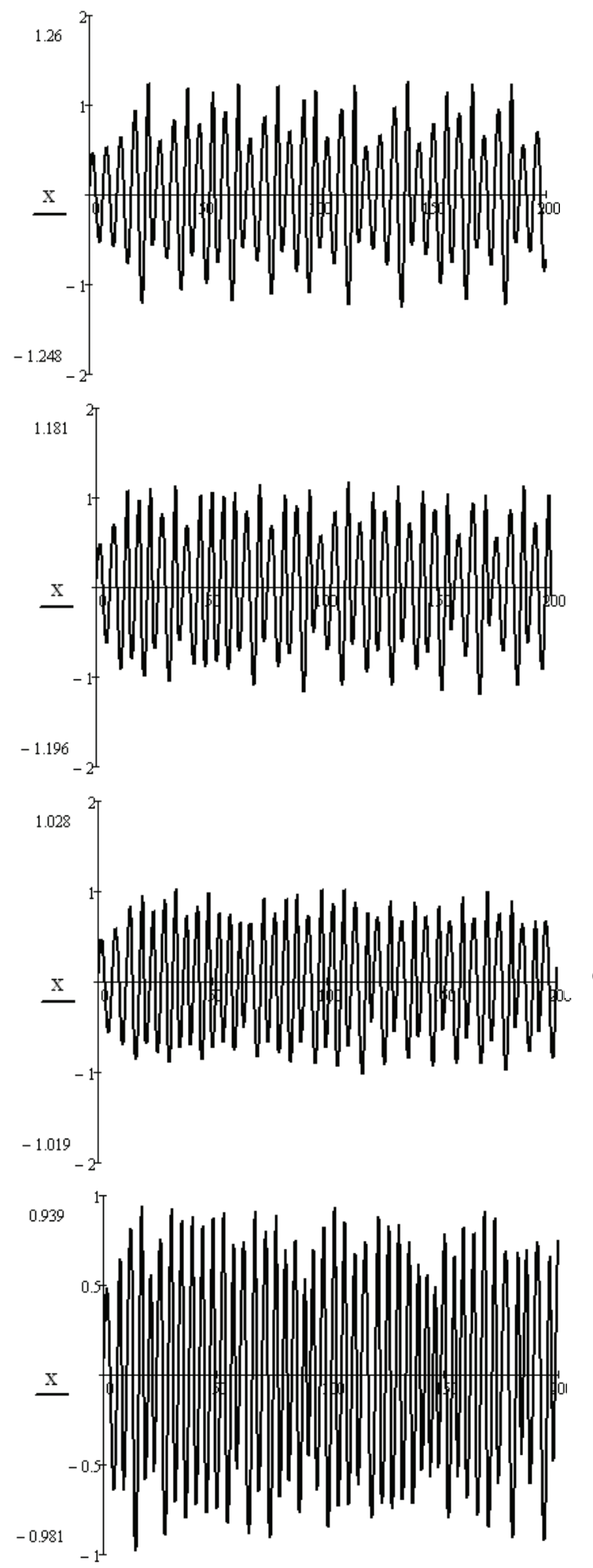

a)

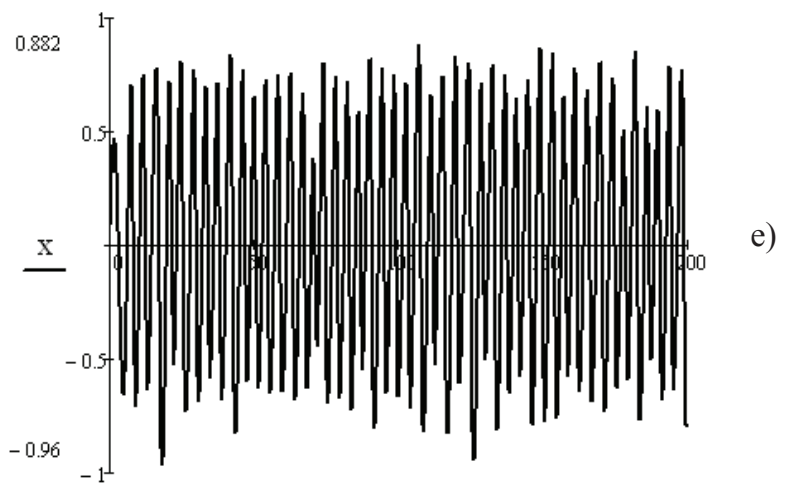

Fig. 12. The graphs of the normalized variable $x$ depending on normalized time $T=\omega_{0} t$, when $\mathrm{g}=0.957, \mathrm{~d}=0.2, \varepsilon=0.2$, $\mathrm{h}=0.15$ and a) $\mathrm{D}=0.0$ (without noise), b) $\mathrm{D}=0.01$, c) $\mathrm{D}=0.05$, d) $\mathrm{D}=0.1, \mathrm{e}) \mathrm{D}=0.15$

\section{Conclusion}

In the paper the mathematical model describing the dynamic processes in the Kiyashko-PikovskyRabinovich oscillator based on the field-effect transistor structure with negative resistance in presence and in absence of additive white Gaussian noise has been proposed. The phase portraits, time and frequency dependences of the generated oscillation in presence and in absence of additive white noise having various intensity have been obtained.

The chaotic oscillation dynamics changes slightly due to the oscillator's amplifier non-linear properties, which are strongly influenced by the additive Gaussian noise. The additive white Gaussian noise impact on the chaotic oscillation dynamics for the KPR oscillator based on the field-effect transistor structure with negative resistance was defined as taking place at noise intensity of level $\mathrm{D}=0.01$ and more by means of mathematical simulation. It confirms the higher noisestability of the KPR oscillator comparing to the classical oscillator of Van-der-Pol $[11,12]$. In that case dynamics of the KPR oscillator changes significantly at the additive white Gaussian noise level of $\mathrm{D}=0.125$. Also the generated chaotic oscillation becomes oscillatory ones with random amplitude and phase modulations. The stable generation mode for the oscillation of oscillatory type with random amplitude and phase modulations is observed at noise level up to $\mathrm{D}=0.437$, and its exceeding leads to suppression of oscillation.

\section{References}

1. M. P. Kennedy, R. Rovatti, and G. Setti. Chaotic Electronics in Telecommunications. - London: CRC Press, 2000. - 447 p. 
2. O primenenii chaoticheskoy synchronyzatsii dlya skrytoy peredachi informatsii / A.A. Koronovskii, O.I. Moskalenko, and A.E. Hramov // Uspekhi Fizicheskikh Nauk. - 2009. - No 179 (12). - P. 1281-1310 [in Russian].

3. Statisticheskie svostva dynamicheskogo chaosa / V.S. Anishchenko, T.E. Vadivasova, G.A. Okrokvertskhov, and G.I. Strelkova // Uspekhi Fizicheskikh Nauk. - 2005. - No 175 (2). - P. 163-179 [in Russian].

4. Vliyanie shuma na avtogenerator spiralnogo chaosa / A.S. Zakharova, T.E. Vadivasova, and V.S. Anishchenko // Izvestie vuzov Prikladnaya Nelineynaya Dinamica. - 2005. Vol. 14, No 5. - P. 44-61 [in Russian].

5. USSR Patent 698118, H 03 B 29/00. The random signals oscillator / S.V. Kiyashko, A.S. Pikovsky and M.I. Rabinovich // Claim 23.03.1978; Print 15.11.1979. Vol. №42, 1979. -3 p. [in Russian].

6. S.P. Kuznetsov. Dynamical Chaos. Second Edition. Moscow: Fizmatlit, 2006. - 295 p [in Russian].

7. Mathematical simulation of the chaotic oscillator based on a field-effect transistor structure with negative resistance / Andriy Semenov // 2016 IEEE 36th International Conference on Electronics and Nanotechnology (ELNANO), Kyiv, Ukraine, April 19-21, 2016. - Kyiv: National Technical University of Ukraine "Kyiv Polytechnic Institute", 2016. P. 52-56.

8. Umesh Kumar, "A complication of negative resistance circuits generated by two novel algorithms," Active and Passive Elec. Comp., Vol. 25, 2002, pp. 211-214.
9. Reviewing the Mathematical Models and Electrical Circuits of Deterministic Chaos Transistor Oscillators / Andriy Semenov // Proceedings of the International Siberian Conference on Control and Communications (SIBCON). Moscow: National Research University "Higher School of Economics". Russia, Moscow, May 12-14, 2016.

10. I.O. Anisimov. Kolyvannya ta chvyli. Navchalnyy posibnyk. - Kyiv: Press of the Taras Shevchenko National University of Kyiv, 2001. - 218 p [in Ukraine].

11. The Van der Pol's Mathematical Model of the Voltage-Controlled Oscillator Based on a Transistor Structure With Negative Resistance / Andriy Semenov // Proceedings of the XIII International Conference Modern problems of radio engineering, telecommunications, and computer science (TCSET-2016), Lviv-Slavsko, Ukraine, February 23-26, 2016. - P. 100-104,

12. The Chaos Oscillator with Inertial Non-Linearity Based on a Transistor Structure with Negative Resistance / Andriy O. Semenov, Alexander V. Osadchuk, Iaroslav A. Osadchuk, Kostyantyn O. Koval, and Maksym O. Prytula // Proceedings of the 17th International Conference of Young Specialists on Micro/Nanotechnologies and Electron Devices EDM 2016, Erlagol, Altai, Russia, 30 June - 4 July, 2016. P. 178-184.

Received in final form on September 16, 2016

\section{Семенов А.O.}

Генератор детермінованого хаосу на основі польової транзисторної структури 3 від'смним опором для телекомунікаційних систем

Проблематика. Застосування генераторів детермінованого хаосу в телекомунікаційних системах потребує знання їхніх динамічних властивостей. Відомі математичні моделі та фазові портрети таких генераторів. Але загальна теорія генераторів детермінованого хаосу розроблена за умови відсутності шумів. У той час, як практичне застосування цих генераторів у телекомунікаційних системах здійснюється за умови наявності як внутрішніх, так і зовнішніх шумів. Тому актуальною прикладною науковою задачею $\epsilon$ дослідження впливу шуму на динаміку коливань у генераторі детермінованого хаосу.

Мета досліджень. Створення математичних моделей генератору детермінованого хаосу типу Кияшко-ПіковськогоРабіновича на основі польової транзисторної структури з від’ємним опором за відсутності та при наявності адитивного білого шуму.

Методика реалізації. На підставі використання відомої математичної моделі Кияшко-Піковського-Рабіновича та нелінійної апроксимації статичної вольт-амперної характеристики польової транзисторної структури за допомогою функції гіперболічного тангенсу досліджено динаміку хаотичних коливань в генераторі. Отримано результати математичного моделювання генератору детермінованого хаосу за відсутності та при наявності адитивного білого шуму. Оцінено вплив адитивного білого шуму на динаміку та параметри генерованих хаотичних коливань.

Результати досліджень. Отримано фазові портрети, часові та частотні характеристики коливань за відсутності та при наявності шуму в генераторі детермінованого хаосу на основі польової транзисторної структури з від'ємним опором.

Висновки. Отримані результати чисельного моделювання динаміки хаотичних коливань за наявності адитивного білого шуму підтверджують високу завадостійкість генератору детермінованого хаосу на основі польової транзисторної структури з від'ємним опором.

Ключові слова: генератор; хаос; коливання; фазовий портрет; білий шум.

Семёнов А. $А$.

Генератор детерминированного хаоса на основе полевой транзисторной структуры с отрицательным сопротивлением для телекоммуникационных систем 
Проблематика. Применение генераторов детерминированного хаоса в телекоммуникационных системах требует знания их динамических свойств. Известны математические модели и фазовые портреты таких генераторов. Однако общая теория генераторов детерминированного хаоса разработана при условии отсутствия шумов. В то же время, как практическое использование этих генераторов в телекоммуникационных системах осуществляется при условии наличия как внутренних, так и внешних шумов. Поэтому актуальной прикладной научной задачею есть исследование влияния шума на динамику колебаний в генераторе детерминированного хаоса.

Цель исследований. Создание математических моделей генератора детерминированного хаоса типа КияшкоПиковського-Рабиновича на основе полевой транзисторной структуры с отрицательным сопротивлением при отсутствии и при наличии аддитивного белого шума.

Методика реализации. На основании использования известной математической модели Кияшко-ПиковськогоРабиновича и нелинейной аппроксимации статической вольтамперной характеристики полевой транзисторной структуры с помощью функции гиперболического тангенса исследовано динамику хаотических колебаний в генераторе. Получены результаты математического моделирования генератора детерминированного хаоса при отсутствии и при наличии аддитивного белого шума. Оценено влияние аддитивного белого шума на динамику и параметры генерированных хаотических колебаний.

Результаты исследований. Получены фазовые портреты, часовые и частотные характеристики колебаний при отсутствии и при наличии шума в генераторе детерминированного хаоса на основе полевой транзисторной структуры с отрицательным сопротивлением.

Выводы. Полученные результаты численного моделирования динамики хаотических колебаний при наличии аддитивного белого шума подтверждают высокую помехоустойчивость генератора детерминированного хаоса на основе полевой транзисторной структуры с отрицательным сопротивлением.

Ключевые слова: генератор; хаос; колебания; фазовый портрет; белый шум. 